\title{
SEEDLING EMERGENCE AND GENETIC PARAMETERS OF OPEN- POLLINATED CANDEIA PROGENIES GROWN IN TREE NURSERY
}

\author{
Maria Lopes Martins Avelar ${ }^{1 *}$, Vitor Passos da Silva Júnior², Lucas Rodrigues Rosado ${ }^{3}$, Flávia Maria Avelar \\ Gonçalves ${ }^{4}$, Adriano José Pavan ${ }^{5}$, Lucas Amaral de Melo ${ }^{6}$ \\ ${ }^{1 *}$ Universidade Federal de Lavras, Programa de Pós-Graduação em Engenharia Florestal, Departamento de Ciências Florestais, Lavras, \\ Minas Gerais, Brasil - maria.1ma@ hotmail.com \\ ${ }^{2}$ Bracell, Melhoramento Genético, Lençóis Paulista, São Paulo, Brasil - vitorpsjunior@ hotmail.com \\ ${ }^{3}$ Universidade Federal de Lavras, Pós-Graduação em Genética e Melhoramento de Plantas, Departamento de Biologia, Lavras, Minas Gerais, \\ Brasil - lucasrosado@yahoo.com.br \\ ${ }^{4}$ Universidade Federal de Lavras, Departamento de Biologia, Lavras, Minas Gerais, Brasil - fmavelarg@gmail.com \\ ${ }^{5}$ Universidade Federal de Lavras, Programa de Pós-Graduação em Tecnologias e Inovações Ambientais, Lavras, Minas Gerais, Brasil - \\ adrianojosepavan@gmail.com \\ ${ }^{6}$ Universidade Federal de Lavras, Departamento de Ciências Florestais, Lavras, Minas Gerais, Brasil - lucas.amaral@ufla.br
}

Received for publication: 14/02/2020 - Accepted for publication: 26/02/2021

\begin{abstract}
Resumo
Emergência de plântulas e parâmetros genéticos de progênies de polinização aberta de candeia em viveiro. Eremanthus erythropappus (DC.) MacLeish é uma espécie nativa, apreciada economicamente devido a sua madeira e à extração de óleo essencial, cujo princípio ativo é o alfabisabolol. Apesar da importância econômica, os estudos em melhoramento genético dessa espécie ainda são escassos. Objetivou-se determinar o percentual de emergência, parâmetros genéticos e identificar potenciais progênies de polinização aberta de $E$. erythropappus e suas respectivas matrizes. O experimento foi implantado em viveiro, em delineamento experimental inteiramente ao acaso, com 22 progênies em quatro repetições, contendo 14 mudas por parcela. Aos 30 dias após a semeadura foi avaliado o percentual de emergência, enquanto aos 100 dias foram realizadas mensurações para altura (A) e diâmetro do coleto (DC). As análises estatísticas foram realizadas por meio do método REML/BLUP. Três progênies apresentaram percentual de emergência abaixo de 50\%, valor considerado limitante para o processo de produção de mudas. Verificou-se a existência de variação genética entre as progênies e correlação genética alta e positiva entre A e DC. Dessa forma, foi possível identificar progênies e matrizes superiores bem como aquelas com baixo desempenho nas características avaliadas.

Palavras-chave: REML/BLUP; Eremanthus erythropappus; teste de progênies.
\end{abstract}

\begin{abstract}
Eremanthus erythropappus (DC.) MacLeish is economically appreciated due to its wood and to the extraction of its essential oil, whose active principle is alpha-bisabolol. Despite its economic importance, studies about the genetic breeding of this species remain scarce. The aim of the current study is to determine E. erythropappus seedling emergence rate, genetic parameters, as well as to identify potential open-pollinated progenies of this species and their respective matrices. The experiment was set up in tree nursery, based on a completely randomized design, with 22 progenies in four replicates comprising 14 plants per plot. Seedling emergence rate was evaluated 30 days after seeding, whereas plant height $(\mathrm{H})$ and stem diameter $(\mathrm{SD})$ were measured at 100 days. Statistical analyses were carried out based on the REML/BLUP method. Three progenies have shown seedling emergence rate lower than 50\%; this value is considered limiting to seedling production process. Genetic variation was observed among progenies, as well as high and positive genetic correlation between $\mathrm{H}$ and SD. Thus, it was possible identifying superior progenies and matrices, as well as the ones presenting low performance in the evaluated traits.
\end{abstract}

Keywords: REML/BLUP; Eremanthus erythropappus; progeny test.

\section{INTRODUCTION}

Eremanthus erythropappus (DC.) MacLeish is an allogamous native tree species belonging to family Asteraceae - popularly known as candeia - which grows in shallow and low-fertility soils (SCOLFORO et al., 2012). It naturally grows between forests and rupestrian fields, as well as between altitude fields and Cerrado, at altitudes ranging from 900 to $1,700 \mathrm{~m}$. In addition, it is typically found in Goiás, Minas Gerais, Espírito Santo, São Paulo and Rio de Janeiro States, as well as in the Federal District (SCOLFORO et al., 2012). The natural resistance of its wood to xylophagous agents enables making high-quality fence posts (SCOLFORO et al., 2016). Moreover, the essential oil produced by this species is extracted from its leaves, branches and inflorescences, mainly from its stem. Alpha-bisabolol, which has dermatological, cosmetic, insecticidal, anti-inflammatory, antibacterial and antiallergic properties (KAMATOU; VILJOEN, 2009), is the main component of the species essential oil and it is widely used in the industrial sector.

Natural populations of this species - the so-called candeal - have been intensively exploited due to its economic importance (SILVA et al., 2014). Its exploitation has reduced the natural occurrence area of the species.

FLORESTA, Curitiba, PR, v. 51, n. 3, p. 639-647, jul/set 2021.

Avelar, M. L. M. et.al.

ISSN eletrônico 1982-4688

DOI: $10.5380 /$ rf.v51 i3. 71735 
Thus, it is necessary conducting research about silviculture and genetic improvement of candeia species to enable selecting its best provenances and progenies (MELO et al., 2012). Studies focused on investigating the genetic improvement of this species have already been carried out, based on the implantation and conduction of provenance and progeny tests in Southern Minas Gerais State, most specifically in Baependi and Aiuruoca counties, where early genetic evaluations and selections are continuously carried out.

Genetic performance in breeding programs based on progenies is evaluated through genetic values, which are used to select progenies or even genetically superior individuals, based on the traits of interest (PIRES et al., 2013). In addition, estimates of variance components and genetic parameters such as heritability, genetic variation coefficient and genetic correlation enable estimating the expected genetic gains resulting from the selection and monitoring of genetic variability of traits over time (OTSUBO et al., 2015).

Different tree matrices can show different seed germination and seedling emergence percentages, as well as variations in initial growth traits such as plant height and stem diameter (MONTEIRO et al., 2016). Therefore, it is important analyzing seedling production feasibility, based on seed germination and seedling emergence, in order to improve species selection processes (MARTINS et al., 2013), since seedling production costs can have major impact on the net revenue of production forests. The investment in seeds with good genetic quality results in seedlings with good growth vigor and considerably increases the yield and profits deriving from commercial reforestation processes.

Therefore, the aim of the current study was to evaluate the seedling emergence percentage, the genetic variability, as well as to identify potential open-pollinated E. erythropappus progenies and their respective tree matrices, based on estimates of genetic parameters calculated at seedling stage. Based on the hypotheses of the present study, progenies present different seedling emergence percentages, as well as genetic variability between them. There is genetic correlation between plant height $(\mathrm{H})$ and stem diameter (SD).

\section{MATERIALS AND METHODS}

\section{Study site and experimental material}

The experiment was carried out in a seedling production tree nursery located in Southern Minas Gerais State (latitude $21^{\circ} 14^{\prime} \mathrm{S}$; longitude $44^{\circ} 59^{\prime} \mathrm{W}$ and altitude of $919 \mathrm{~m}$ ), which is the natural species occurrence region where commercial E. erythropappus plantations have been implemented to help supplying the wood processing and oil production industry.

Seeds of open-pollinated progenies used for seedling production were collected from 22 tree matrices grown in seed orchard, deriving from provenance and progeny test applied to E. erythropappus, implanted in January 2005 in the rural area of Baependi County, Minas Gerais State and genotypically selected at the age of five and a half years. Trees presenting the highest height, diameter at breast height (DBH) and volume values were selected as seed collection matrices (Table 1).

Table 1. Provenance and location of matrices where seeds were collected at the provenance and progeny test, in Baependi rural area, Minas Gerais State.

Tabela 1. Procedências e localização das matrizes onde foram coletadas sementes no teste de procedências e progênies, localizado em área rural do município de Baependi, Minas Gerais.

\begin{tabular}{lllll}
\hline Progenies in tree nursery & Provenance & Matrices & Block & N of tree in plot \\
\hline 1 & Baependi & 9 & 1 & 2 \\
2 & Baependi & 22 & 6 & 3 \\
3 & Baependi & 20 & 1 & 4 \\
4 & Baependi & 20 & 2 & 4 \\
5 & Morro do Pilar & 8 & 1 & 1 \\
6 & Itabirito & 9 & 2 & 3 \\
7 & Baependi & 22 & 2 & 2 \\
8 & Itabirito & 1 & 1 & 1 \\
9 & Carrancas & 25 & 6 & 1 \\
10 & Itabirito & 1 & 6 & 6 \\
11 & Itabirito & 15 & 5 & 2 \\
12 & Morro do Pilar & 3 & 7 & 2 \\
13 & Carrancas & 11 & 1 & 4 \\
14 & Delfim Moreira & 2 & 2 & 2
\end{tabular}

FLORESTA, Curitiba, PR, v. 51, n. 3, p. 639-647, jul/set 2021. 


\begin{tabular}{lllll}
15 & Itabirito & 18 & 1 & 4 \\
16 & Carrancas & 25 & 1 & 6 \\
17 & Delfim Moreira & 13 & 6 & 5 \\
18 & Delfim Moreira & 2 & 1 & 2 \\
19 & Morro do Pilar & 11 & 1 & 4 \\
20 & Carrancas & 23 & 5 & 6 \\
21 & Morro do Pilar & 11 & 6 & 5 \\
22 & Morro do Pilar & 14 & 1 & 2 \\
\hline
\end{tabular}

Seeds of all 22 progenies were collected in October 2014, identified, separated based on maternal origin (tree matrices), dried in oven until they reached 5\% humidity and manually processed. Fruits were dried in the sun, and macerated on sieve, which had a tray placed underneath it to enable collecting the diaspores. The material in the tray was blown in order to get seed lots with greater purity and viability (SCOLFORO et al., 2012). Subsequently, seeds were stored in cold chamber (at $4{ }^{\circ} \mathrm{C}$ and $70 \%$ humidity), based on the methodology proposed by Tonetti et al. (2006) for seedling production.

\section{Seedling production and experimental design}

Seedlings were produced in tubes (volume of $110 \mathrm{~cm}^{3}$ ) filled with substrate made of $90 \%$ coconut fiber and 10\% vermiculite, added with $4 \mathrm{~kg}$ of slow-release fertilizer (NPK 15:09:12) per $\mathrm{m}^{3}$ of substrate, based on the methodology by Melo et al. (2014). Five seeds were sown per container, which were taken to the shade house, where germination took place from the eighth day onwards. Cover fertilization comprising $1,000 \mathrm{~g}$ of monoammonium phosphate and $100 \mathrm{~g}$ of potassium chloride diluted in $100 \mathrm{~L}$ of water was performed with the aid of watering can, 15 days after sowing. Fungicide $250 \mathrm{SC}$, at concentration of $3 \mathrm{~mL}$ per liter of water, was applied through hand sprayer at 20 days.

Seedling emergence percentage was evaluated 30 days after sowing, by taking under consideration container with at least one emerged seedling. The first selective thinning was carried out at that time and left two seedlings per container. The second selective thinning was performed at 50 days and left only one seedling (the most central and most vigorous) per container. Next, seedlings were transferred to the area in full sun in order to keep growing and start the rustification process.

The second cover fertilization was carried out 70 days after sowing, based on the previously performed

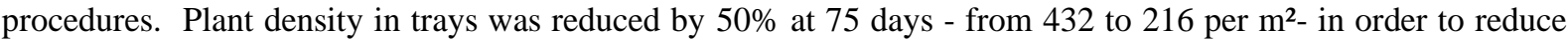
plant competition for light. Plant height $(\mathrm{H})$ and stem diameter (SD) were measured at 100 days. Ruler graduated in centimeters was used to measure $\mathrm{H}$, whereas digital caliper $(0.02 \mathrm{~mm}$ accuracy) graduated in millimeters was used to measure SD. The experiment has followed a completely randomized design with 22 progenies, four replications and 14 tubes per plot - it was carried out from September to December 2015.

\section{Data analysis}

The seedling emergence percentage of each progeny was estimated through the following equation:

$$
E \%=100\left(\frac{n}{N}\right)(1)
$$

Wherein, $\mathrm{n}$ is the number of tubes with emerged seedlings and $\mathrm{N}$ is the total number of tubes per progeny (48). The minimum value defined for the seedling production process corresponded to emergency percentage of $50 \%$.

Seedling variation components and genetic parameters of traits such as $\mathrm{H}$ and SD were estimated based on the REML/BLUP method implemented in SELEGEN software (RESENDE, 2016), by following statistical model 80:

$$
\mathrm{Y}=\mathrm{X} \mu+\mathrm{Zg}+\mathrm{Wp}+\mathrm{e}(2)
$$

Wherein, $\mathrm{Y}$ is the vector of phenotypic data, $\mu$ is the effect of the general mean, $\mathrm{g}$ is the vector of genotypic effects, according to which, $\mathrm{g} \sim \mathrm{MVN}\left(0, \sigma_{\mathrm{g}}\right)$, $\mathrm{p}$ is the vector of plot effects assumed to be $\mathrm{p} \sim \mathrm{MNV}\left(0, \sigma_{\mathrm{p}}\right)$, and $e$ is the vector of errors or residuals, whose e $\sim \operatorname{MVN}\left(0, \sigma_{\mathrm{e}}\right)$. "X", "Z" and "W" represent the incidence matrices for the referred effects (RESENDE, 2016).

Maximum likelihood ratio test (LRT) was used to check significant statistical differences in the investigated effect (progenies) - i.e., whether there was genetic variability between progenies - based on the 
difference in deviances between the complete models and the one with lack of corresponding effect (progenies). The following variance components were also estimated: additive genetic variance between progenies $\left(\sigma_{a}^{2}=4 \sigma_{g}^{2}\right.$ ), estimates assumed the kinship of half-siblings within progenies $(0.25)$, variance between plots $\left(\sigma_{p}^{2}\right)$, environmental variance $\left(\sigma_{e}^{2}\right)$, and phenotypic variance $\left(\sigma_{f}^{2}=\sigma_{a}^{2}+\sigma_{p}^{2}+\sigma_{e}^{2}\right)$. The estimated genetic parameters were:

Individual narrow-sense heritability:

$$
h_{a}^{2}=\frac{\sigma_{a}^{2}}{\sigma_{f}^{2}}(3),
$$

Coefficient to determine the effects of the plot:

$$
C_{p}^{2}=\frac{\sigma_{p}^{2}}{\sigma_{f}^{2}}(4),
$$

Individual additive genetic variation coefficient:

$$
C V_{g i} \%=100\left(\frac{\sqrt{\sigma_{a}^{2}}}{x}\right)(5),
$$

Experimental coefficient of variation:

$$
C V_{e} \%=100\left\{\sqrt{\frac{\left[\left(0.75 \sigma_{a}^{2}+\sigma_{e}^{2}\right) / 3+\sigma_{p}^{2}\right.}{x}}\right\}(6),
$$

Relative coefficient of variation:

$$
C V_{r}=\frac{C V_{g i}}{C V_{e}}(7),
$$

Selective accuracy was estimated based on Resende and Duarte (2007):

$$
\widehat{r_{g g}}=\left[\frac{1}{1+\left(C V_{e}^{2} / C V_{g i}^{2}\right) / r}\right]^{\frac{1}{2}}(8)
$$

Wherein, $x$ is the general mean of the analyzed trait and $r$ is the number of repetitions.

Means (individual BLUP) of the two traits evaluated in the investigated progenies were predicted based on the previously defined statistical model. Seedlings with predicted mean height greater than $25 \mathrm{~cm}$ were defined as truncated selection criterion. Selection intensity of 55\% was adopted to promote accumulated genetic gain in relation to the mean of traits, without significantly reducing genetic variability. This value corresponds to the twelve best progenies identified for each trait, based on the truncated selection criterion. Percentage gain was obtained by dividing the value recorded for the accumulated genetic gain of the selected progenies by the overall mean of the investigated trait and by multiplying it by 100. Predicted means were obtained based on the sum of the overall mean of selected progenies and the accumulated genetic gain.

Genetic correlation between H and SD was estimated through BLUPs, in the R Core Team (2018) statistical software, in order to analyze whether direct selection based on one trait can lead to indirect gains in the other one.

\section{RESULTS}

\section{Seedling emergence}

Matrices have shown differences in seedling emergence (Figure 1). Progenies 5, 15 and 17 have shown seedling emergence percentages lower than $50 \%-26 \%, 33.4 \%$ and $24.3 \%$, respectively. The other progenies have 
shown seedling emergence percentages higher than $70 \%$ and progenies 11 and 18 have reached $100 \%$ seedling emergence.

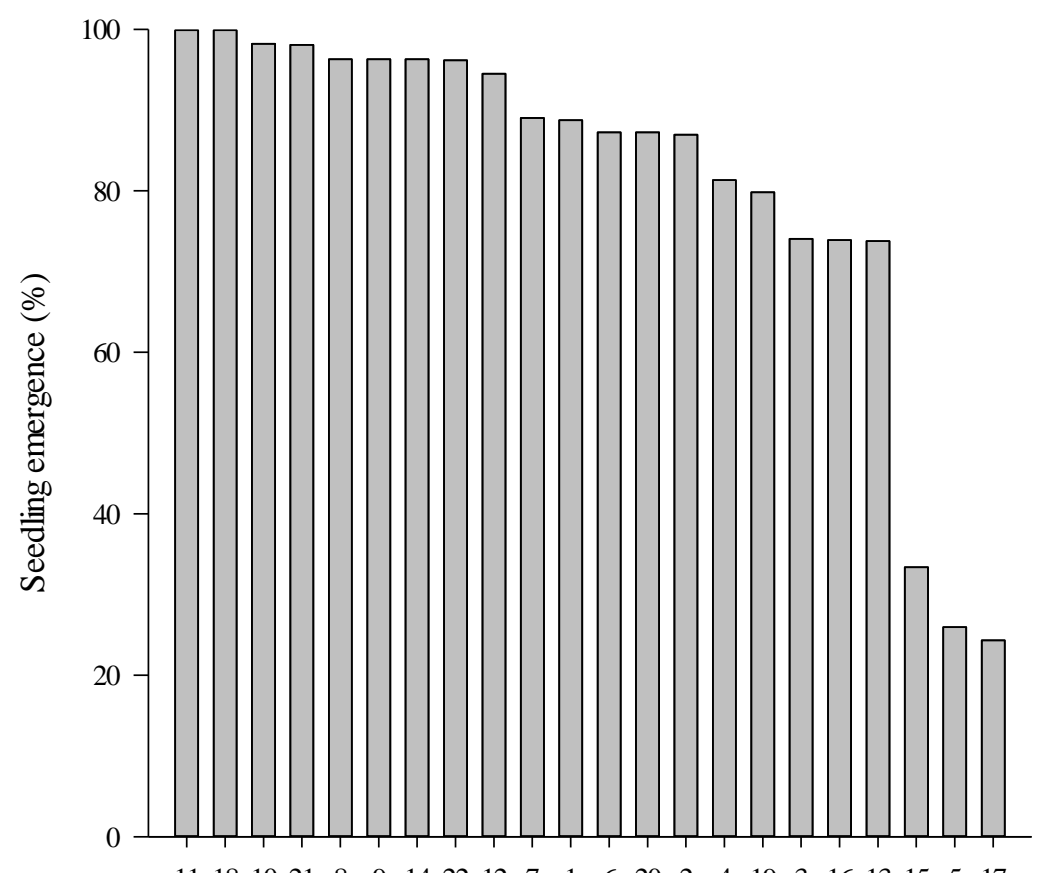

Progeny

Figure 1. Eremanthus erythropappus seedling emergence percentage evaluated 30 days after seeding.

Figura 1. Percentual de emergência de plântulas de Eremanthus erythropappus, avaliada aos 30 dias após a semeadura.

\section{Genetic parameters}

Deviance analysis has shown significant differences in traits $\mathrm{H}$ and SD between progenies (Table 2). The coefficient of individual narrow-sense heritability $\left(h_{a}^{2}\right)$ was high in $\mathrm{H}(0.54)$ and medium in SD (0.25). The coefficient used to determine environmental effects between plots $\left(C_{p}^{2}\right)$ has indicated low variability between plots - $10 \%$ in $\mathrm{H}$ and $4 \%$ in SD. The individual additive genetic variation coefficient $\left(C V_{g i} \%\right)$ has shown considerable genetic variability in both traits $-18.1 \%$ in $\mathrm{H}$ and $11.2 \%$ in SD - whereas the estimated selective accuracy was high in $\mathrm{H}(97.4 \%)$ and SD (97.3\%).

Table 2. Deviance analysis (ANADEV) and genetic parameters linked to plant height (H) and stem diameter (SD) of Eremanthus erythropappus progenies evaluated 100 days after seeding.

Tabela 2. Análise de deviance (ANADEV) e parâmetros genéticos referentes à altura (A) e ao diâmetro do coleto (DC) de mudas de progênies de Eremanthus erythropappus, avaliadas aos 100 dias após a semeadura.

\begin{tabular}{lll}
\hline \multicolumn{1}{c}{ Parameter } & $\mathrm{H}(\mathrm{cm})$ & $\mathrm{SD}(\mathrm{mm})$ \\
\hline Maximum likelihood ratio test (LRT) & $124.31^{*}$ & $4.98^{*}$ \\
\hline Additive genetic variance: $\sigma_{a}^{2}$ & 17.02 & 0.11 \\
\hline Variance between plots: $\sigma_{p}^{2}$ & 3.27 & 0.02 \\
\hline Environmental variance: $\sigma_{e}^{2}$ & 11.27 & 0.31 \\
\hline Phenotypic variance: $\sigma_{f}^{2}$ & 31.56 & 0.43 \\
\hline Individual narrow-sense heritability: $h_{a}^{2} \pm$ standard deviation & $0.54 \pm 0.13$ & $0.25 \pm 0.09$ \\
\hline Coefficient used to determine the effects of the plot: $C_{p}^{2}$ & 0.10 & 0.04 \\
\hline
\end{tabular}

FLORESTA, Curitiba, PR, v. 51, n. 3, p. 639-647, jul/set 2021. 


\begin{tabular}{lll}
\hline Individual additive genetic variation coefficient: $C V_{g i} \%$ & 18.1 & 11.2 \\
\hline Experimental coefficient of variation: $C V_{e} \%$ & 8.4 & 5.3 \\
\hline Relative coefficient of variation: $C V_{r}$ & 2.15 & 2.11 \\
\hline General mean & 22.82 & 2.91 \\
\hline
\end{tabular}

*Significant at $5 \%$ probability of error. Tabulated Chi-square: 3.84 at $5 \%$ significance level.

*Significativo a 5\% de probabilidade de erro. Qui-quadrado tabelado: 3,84 para os níveis de significância de 5\%.

Table 3. Mean components (individual BLUP) of the 12 best (55\% of total) Eremanthus erythropappus progenies selected based on traits such as plant height $(\mathrm{cm})$ and stem diameter $(\mathrm{mm})$.

Tabela 3. Componentes de média (BLUP individual) das 12 melhores progênies (55\% do total) de Eremanthus erythropappus, selecionadas de acordo com os caracteres altura $(\mathrm{cm})$ e diâmetro do coleto $(\mathrm{mm})$.

\begin{tabular}{|c|c|c|c|c|c|c|c|c|}
\hline \multirow[b]{2}{*}{ Order } & \multicolumn{4}{|c|}{ Plant height $(\mathrm{cm})$} & \multicolumn{4}{|c|}{ Stem diameter $(\mathrm{mm})$} \\
\hline & Progeny & $\begin{array}{l}\text { Additive } \\
\text { effect (a) }\end{array}$ & Gain & $\begin{array}{l}\text { Predicted } \\
\text { mean }(\mathrm{cm})\end{array}$ & Progeny & $\begin{array}{l}\text { Additive } \\
\text { effect (a) }\end{array}$ & Gain & $\begin{array}{l}\text { Predicted } \\
\text { mean }(\mathrm{mm})\end{array}$ \\
\hline 1 & 21 & 7.04 & 7.04 & 29.86 & 13 & 0.52 & 0.52 & 3.42 \\
\hline 2 & 8 & 5.86 & 6.45 & 29.27 & 12 & 0.40 & 0.46 & 3.37 \\
\hline 3 & 13 & 5.36 & 6.09 & 28.91 & 4 & 0.40 & 0.44 & 3.35 \\
\hline 4 & 12 & 2.24 & 5.12 & 27.94 & 8 & 0.18 & 0.38 & 3.28 \\
\hline 5 & 11 & 1.80 & 4.46 & 27.28 & 1 & 0.15 & 0.33 & 3.24 \\
\hline 6 & 7 & 1.75 & 4.01 & 26.83 & 11 & 0.13 & 0.30 & 3.21 \\
\hline 7 & 14 & 1.31 & 3.62 & 26.44 & 9 & 0.10 & 0.27 & 3.18 \\
\hline 8 & 9 & 1.07 & 3.30 & 26.12 & 18 & 0.10 & 0.25 & 3.16 \\
\hline 9 & 2 & 1.00 & 3.05 & 25.87 & 14 & 0.08 & 0.23 & 3.14 \\
\hline 10 & 20 & 0.66 & 2.81 & 25.63 & 21 & 0.04 & 0.21 & 3.12 \\
\hline 11 & 4 & 0.49 & 2.60 & 25.42 & 2 & 0.04 & 0.20 & 3.10 \\
\hline 12 & 18 & 0.46 & 2.42 & 25.24 & 7 & 0.04 & 0.18 & 3.09 \\
\hline \multicolumn{3}{|c|}{ General mean } & & 22.82 & & & & 2.91 \\
\hline
\end{tabular}

The selection of the 12 best progenies enabled gain in $\mathrm{H}$ and SD by $10.6 \%$ and $6.2 \%$, respectively, in relation to the general mean (Table 3). In addition, $11(2,4,7,8,9,11,12,13,14,18$ and 21$)$ of the 12 progenies selected based on $\mathrm{H}$ have also shown greater gain in SD.

Progeny 5 recorded the lowest values for additive effects, which are inheritable, i.e., they are passed on from parents to progeny (-7.66 for $\mathrm{H}$, and -0.55 for $\mathrm{SD}$ ). This progeny has also presented one of the lowest seedling emergence percentages. Similar outcome was observed for progenies 15 and 17, which indicates their low performance in the analyzed traits, as well as their difficulty in producing seedlings due to their low emergence, in comparison to other progenies. There was high genetic correlation between plant height and stem diameter 100 days after sowing $(0.72)$.

\section{DISCUSSION}

\section{Seedling emergence}

Some progenies can be ruled out if one takes into consideration that the percentage of $50 \%$ was set as minimum value for seedling production. Therefore, despite the high genotypic value presented by progenies 5,15 and 17 , it is not recommended using them because their seedling production is highly costly, and they present low seedling emergence percentage. The other progenies presented seedling emergence percentages higher than $70 \%$; thus, they can be indicated for selection processes due to their high seedling emergence percentage, which, in association with growth in $\mathrm{H}$ and $\mathrm{SD}$, helps optimizing the production process and makes its seedlings suitable for planting (LISBOA et al., 2018; MELO et al., 2018).

\section{Genetic parameters}

The genetic variability observed between progenies has indicated likely successful selection process (PINTO et al., 2014) and good prospects for gains based on the selection of the best progenies, although they were evaluated at seedling stage. In addition, according to the heritability classification suggested by Resende (1995), the estimate of individual narrow-sense heritability $\left(h_{a}^{2}\right)$ presented high magnitude for $\mathrm{H}(0.54)$ and medium 
magnitude for SD (0.25). Such estimates have indicated that part of the phenotypic variation of the analyzed traits had genetic nature (RAMALHO et al., 2012).

Results recorded for heritability were similar to the ones reported for Cedrella fissilis progenies, 102 days after sowing - 0.52 for $\mathrm{H}$ and 0.42 for SD (BIERNASK et al., 2012). However, they were lower than the ones recorded for Eugenia calycina progenies 150 days after sowing - 0.76 for $\mathrm{H}$ and 0.87 for SD, (FREITAS; COSTA, 2015).

The greater the value recorded for coefficients of individual additive genetic variation ( $\left.C V_{g i} \%\right)$, the greater the likelihood of getting genetic gains in the selection process, since there was genetic variability between progenies. This finding has evidenced that most of the total variation resulted from genetic causes (RESENDE, 2002). Values recorded for $\mathrm{H}(18.1 \%)$ and SD (11.2\%) were considered high and corroborated values observed by Chinelato et al. (2014), who investigated Schizolobium parahyba progenies (11\% for plant height at 60 days).

According to Henderson (1984), selective accuracy is the most important statistical parameter in genotypic evaluations, since it correlates the true genotypic value to the one estimated or predicted through experiments. This parameter ranges from 0 to 1 ; the closest values to 1 are the highest and most suitable values for it. Selective accuracy values recorded for H (97.4\%) and SD (97.3\%) were considered to have high magnitude, values that showed high experimental precision level (RESENDE; DUARTE, 2007). The herein recorded high precision values make selection at seedling level feasible and may lead to genetic gain in a shorter period-of-time.

The truncated selection criterion set for plant height (progenies with mean height higher than $25 \mathrm{~cm}$ ) was defined based on predicted means (individual BLUP) recorded for the selection of the 12 best progenies in $\mathrm{H}$, and of the 12 best progenies in SD. According to Melo et al. (2014), E. erythropappus seedlings without genetic improvement and grown in substrate added with coconut fiber can reach mean height higher than $20 \mathrm{~cm}, 110$ days after sowing.

Thus, matrices located in the seed orchard that provided seeds of the 11 progenies recording the greatest gains in $\mathrm{H}$ and SD should be indicated for collection processes focused on producing seedlings the most suitable $\mathrm{H}$ and SD for planting, by taking into consideration 100-day production cycles. In addition, seedlings grown from these progenies could be taken to the field, depending on the appropriate edaphoclimatic conditions for the species, and implanted in progeny tests to further the investigation about forestry and genetic improvement of species $E$. erythropappus.

\section{Genetic correlation}

Genetic correlations observed between traits enabled inferring whether direct selection based on one trait can favor other traits and provide indirect gains. Seedlings presented positive and high estimated genetic correlation between H and SD (0.72) 100 days after sowing. According to Pinto et al. (2014), if the genetic correlation is high and positive, selection processes based on one variable has positive influence on the other variable. Thus, direct selection based on plant height can help obtaining indirect gains in stem diameter.

\section{CONCLUSIONS}

- It is not recommended producing seedlings belonging to progenies 5, 15 and 17 because they present low seedling emergence percentage because it hinders the production process.

- Genetic variability in plant height and stem diameter of E. erythropappus progenies at seedling stage enables successful genetic selection and allows identifying suitable matrices for seed collection purposes.

- Progenies 2, 4, 7, 8, 9, 11, 12, 13, 14, 18 and 21 must be selected to help generating larger seedlings to be planted in the field at 100 days of production, whereas their respective matrices should be used for seed collection.

- Indirect gains in stem diameter can be obtained through progenies selection based on plant height due to high and positive genetic correlation between the two traits.

\section{ACKNOWLEDGMENT}

We thank the Citróleo Group for proving areas for the installation of progeny tests and for financing silvicultural activities in the field, the National Council of Technological and Scientific Development (CNPq) for the financial support of the research project (Proc. No 408927/2016-0) and the Research Support Foundation of the State of Minas Gerais (FAPEMIG) for the scholarship. 


\section{REFERENCES}

BIERNASKI, F. A.; HIGA, A. R.; SILVA, L. D. Variabilidade genética para caracteres juvenis de progênies de Cedrela fissilis VELL.: subsídio para definição de zonas de coletas e uso de sementes. Revista Árvore, Viçosa, v. 36, n. 1, p. 49-58, jan./fev. 2012.

CHINElATO, F. C. S.; MORAES, C. B.; CARIGNATO, A.; TAMBARUSSI, E. V.; ZIMBACK, L.; PALOMINO, E. C.; MORI, E. S. Variabilidade genética em progênies de guapuruvu Schizolobium parahyba. Scientia Agropecuaria, Trujillo, v. 5, n. 2, p. 71-76, jun. 2014.

FREITAS, M. B. F.; COSTA, R. R. G. F. Estimativas dos componentes de variância genética entre e dentro de progênies de pitanga-vermelha. Global Science and Technology, Rio Verde, v. 8, n. 3, p. 78-86, dez. 2015.

HENDERSON, C.R. Aplications of linear models in animal breeding. University of Guelph, Guelph. 462 p., 1984.

KAMATOU, G. P. P.; VILJOEN, A. M. A review of the application and pharmacological properties of $\alpha$-bisabolol and $\alpha$-bisabolol-richoils. Journal of the American Oil Chemists'Society, Champaign, v. 87, n. 1, p. 1-7, jan. 2009.

MARTINS, C. C.; BOVI, M. L. A.; OLIVEIRA, S. S. C.; VIEIRA, R. D. Emergência e crescimento inicial de plântulas de Archontophoenix cunninghamiana H. Wendl. \& Drude provenientes de sementes de diferentes plantas matrizes. Ciência Rural, Santa Maria, v. 43, n. 6, p. 1006-1011, mai. 2013.

MELO, L. A.; ABREU, A. H. M.; LELES, P. S. S.; OLIVIEIRA, R. R.; SILVA, D. T. Qualidade e crescimento inicial de mudas de Mimosa caesalpiniifolia Benth. produzidas em diferentes volumes de recipientes. Ciência Florestal, Santa Maria, v. 28, n. 1, p. 47-55, jan./mar. 2018.

MElO, L. A.; PEREIRA, G. A.; MOREIRA, E. J. C.; DAVIDE, A. C.; SIlVA, E. V.; TEIXEIRA, L. A. F. Crescimento de mudas de Eucalyptus grandis e Eremanthus erythropappus sob diferentes formulações de substrato. Revista Floresta e Ambiente, Seropédica, v. 21, n. 2, p. 234-242, jun. 2014.

MELO, L. A.; DAVIDE, A. C.; TEIXEIRA, L. A. F. Metodologia para resgate de matrizes e enraizamento de estacas de Eremanthus erythropappus. Cerne, Lavras, v. 18, n. 4, p. 631-638, out./dez. 2012.

MONTEIRO, R. A.; FIOREZE, S. L.; NOVAES, M. A. G. Variabilidade genética de matrizes de Erythrina speciosa a partir de caracteres morfológicos. Scientia Agraria Paranaensis, Marechal Cândido Rondon, v. 15, n. 1, p. 48-55, mar. 2016.

LiSBOA, A. C.; MElO JUNiOR, C. J. A. H.; TAVARES, F. P. A.; AlMEIDA, R. B.; MELO, L. A.; MAGISTRALI, I. C. Crescimento e qualidade de mudas de Handroanthus heptaphyllus em substrato com esterco bovino. Pesquisa Florestal Brasileira, Colombo, v. 38, n. 93, p. 1-6, jul. 2018.

OTSUBO, H. C. B.; MORAES, M. L. T.; MORAES, M. A.; JOSÉ NETO, M.; FREITAS, M. L. M.; COSTA, R. B.; RESENDE, M. D. V.; SEBBENN, A. M. Variação genética para caracteres silviculturais em três espécies arbóreas da região do bolsão sul-mato-grossense. Cerne, Lavras, v. 21, n. 4, p. 535-544, dez. 2015.

PIMENTEL, A. J. B.; GUIMARÃES, J. F. R.; SOUZA, M. A.; RESENDE, M. D. V.; MOURA, L. M.; ROCHA, J. R. A. S. C.; RIBEIRO, G. Estimação de parâmetros genéticos e predição de valor genético aditivo de trigo utilizando modelos mistos. Pesquisa Agropecuária Brasileira, Brasília, v. 49, n. 11, p. 882-890, nov. 2014.

PINTO, D. S.; RESENDE, R. T.; MESQUITA, A. G. G.; ROSADO, A. M.; CRUZ, C. D. Seleção precoce para característica de crescimento em testes clonais de Eucalyptus urophylla. Scientia Forestalis, Piracicaba, v. 42, n. 102, p. 251-257, jun. 2014.

PIRES, V. C. M.; MARTINS, K.; VILAS BÔAS, O.; FREITAS, M. L. M.; SEBBENN, A. M. Variabilidade genética de caracteres silviculturais em progênies de polinização aberta de Pinus caribaea var. bahamensis. Scientia Forestalis, Piracicaba, v. 41, n. 97, p. 113-119, mar. 2013.

R DEVELOPMENT CORE TEAM. R: a language and environment for statistical computing. Vienna: R Foundation for Statistical Computing, 2018.

RAMALHO, M. A. P.; ABREU, A. F. B.; SANTOS, J. B.; NUNES, J. A. R. Aplicações da genética quantitativa no melhoramento de plantas autógamas. Lavras: Ed. UFLA, 2012. 522 p.

RESENDE, M. D. V. Delineamento de experimentos de seleção para maximização da acurácia seletiva e do progresso genético. Revista Árvore, Viçosa, v. 19, n. 4, p. 479-500, out./dez. 1995. 
RESENDE, M. D. V. Genética biométrica e estatística no melhoramento de plantas perenes. Brasília: Embrapa Informação Tecnológica, 2002. 975 p.

RESENDE, M. D. V.; DUARTE, J. B. Precisão e controle de qualidade em experimentos de avaliação de cultivares. Pesquisa Agropecuária Tropical, Goiânia, v. 37, n. 3, p. 182-194, set. 2007.

RESENDE, M. D. V. Software Selegen-REML/BLUP: a useful tool for plant breeding. Crop Breeding and Applied Biotechnology, Viçosa, v. 16, n. 4, p. 330-339, dez. 2016.

SCOLFORO, J. R. S.; OLIVEIRA, A. D.; DAVIDE, A. C. Manejo sustentável da candeia: o caminhar de uma nova experiência florestal em Minas Gerais. Lavras: Ed. UFLA, 2012. 330 p.

SCOLFORO, J. R. S.; ALTOE, T. F.; SCOLFORO, H. F.; MELLO, J. M.; SILVA, C. P. C.; FERRAZ FILHO, A. C. Management strategies of Eremanthus erythropappus (DC.) MacLeish under different initial spacing. Ciência e Agrotecnologia, Lavras, v. 40, n. 3, p. 298-304, jun. 2016.

SILVA, M. A.; MELO, J. M.; SCOLFORO, J. R. S; CZANCK JUNIOR, L.; ANDRADE, I. S.; OLIVEIRA, A. D. Analysis of the spatial distribution of candeia - Eremanthus erythropappus (DC.) MacLeish-under the seedtree management system. Cerne, Lavras, v. 14, n. 4, p. 311-316, out. 2008.

TONETTI, O. A. O.; DAVIDE, A. C.; SILVA, E. A. A. Qualidade física e fisiológica de sementes de Eremanthus erythropappus (DC.) MacLeish. Revista Brasileira de Sementes, Pelotas, v. 28, n. 1, p. 114-121, abr. 2006. 